\title{
THE USE OF EDMODO IN ESP CLASSROOM: A STUDY ON STUDENTS' PERCEPTION AND CLASSROOM ACTIVITIES
}

\author{
${ }^{1}$ Mariana Ulfah Hoesny, ${ }^{2}$ Hilda Cahyani, ${ }^{3}$ Imam Nur Aziz \\ ${ }^{1}$ English Lecturer, Electro Department, State Polytechnic of Malang, Indonesia \\ ${ }^{2}$ English Lecturer, Business Administration Department, State Polytechnic of Malang \\ ${ }^{3}$ English Lecturer, English Department, Institut Keislaman Abdullah Faqih Gresik \\ Corresponding Author Email: hcahyani@yahoo.com
}

\begin{tabular}{ll}
\hline Article Info & Abstract \\
Article History & This study was aimed at investigating the use of Edmodo, an online learning \\
Received: May 2020 & platform in a Garuda Maintenance Facility class in Electronic Engineering study \\
Revised: June 2020 & program of State Polytechnic of Malang. In addition, students' perception toward \\
Published: July 2020 & the use of Edmodo was also explored to find out the advantages and \\
Keywords & disadvantages of the implementation of Edmodo. This study also investigated \\
Edmodo; & teacher's activities that have been done via Edmodo. The activities done by \\
Online learning; & students via Edmodo are presented in the result of this study to inspire other \\
Students'perception; $;$ & teachers about how to use Edmodo effectively. This study was a case study since \\
ESP classroom; & it described and analyzed a group in a classroom setting to gain understanding \\
& through activities done in the classroom. Survey and interviews were used to \\
& collect the data about students'perception and the description of classroom \\
& activities. The results showed that students had positive perceptions towards the \\
use of Edmodo since it accomodated their need to apply technology in their \\
learning. In addition, it could also encourage shy students who tended to be \\
discouraged when interacted and participated without the aid of online tool in \\
the classroom. Students also mentioned some obstacles encountered during the \\
use of Edmodo such as slow internet connection and limited data package that \\
was needed to connect to the internet. However, it can be concluded that the \\
implementation of Edmodo in GMF class gained positive response. In addition, \\
students also appreciated various activities conducted via Edmodo. It can be \\
added that Edmodo as a learning platform is not only used to replace lecturer's \\
absence, but it can accomodate various learning activities that can increase \\
communication skills in English.
\end{tabular}

How to cite: Hoesny, M. U., Cahyani, H., Aziz, I. N. (2020). The use of edmodo in ESP classroom: A study on students' perception and classroom activities. JOLLT Journal of Languages and Language Teaching, 8(3), 237250, DOI: https://doi.org/10.33394/jollt.v\%vi\%i.2602

\section{INTRODUCTION}

Technology has influenced all parts of people's life today. People use technology for all purposes including learning. The internet is the result of technology, specifically information and communication technology which today become widespread and use by many people all around the world. Due to internet many applications are created for users with various purposes. For example, people now are familiar with transportation application in smartphone like Uber or Grab. In addition, there are a lot more applications that play important role in learning, especially language learning. Learners are getting more familiar with applications like google translate and iTranslator for example. These applications are used to help them translating English to their native language like bahasa Indonesia. Other applications such as Voys and Orai, help learners practice their speaking skill. Padlet is another example in which it provides discussion space for students, thus students who are reluctant to participate in a 
face-to-face discussion can use this tool to join discussion. There are still more applications that are interactive and useful for language learning.

The appearance of web 2.0 also contributes to enrich the learning which is mediated by internet. It can be said that the appearance of Web 2.0 technologies has also helped to promote and maintain the education standards. These tools allow multiple users to participate collaboratively rather than working alone. They offer many functions that appeal to educators who are looking to extend learning beyond the classroom (Haygood, Garner\&Johnson, 2012 in (Al-Kathiri, 2015). (Smaldino, 2015) stated that web 2.0 refers to websites that are more than static webpages compared to its predecessor, web 1.0. Web 2.0 is more interactive since it allows users to take active participation and share idea, information and data through it.

The invention of web 2.0 leads to the invention of many application and learning platform. Edmodo is one of learning platform that is quite popular. It is considered to be secure since it is free from advertisements and games(Inayati, 2019). The two mentioned later is considered to be distractions for students. In line with this, Edmodo is said to be educationfocused social networking sites. It means that it is similar to social networking sites such as Facebook, but Edmodo is intended for learning. (Okumura \& Bronson, 2016) stated that Edmodo is users-friendly for educational purposes since it limits the access only to teachers and students who are already registered. Edmodo also has 'parents feature' to allow parents to see the activities in the platform. Thus parents can also take part in the learning activities which may cause the activities to be more transparent.

Learning in general has shifted from teacher centered to students centered. This affects the implementation of learning in which teacher is not only the source of information in the classrooms. The advancement of technology, especially in the field of internet has made it possible to create learning has more collaborative as well as communicative feature. In addition, learning - especially language learning- which is supported by technology-driven educational environment will be more students-centered and innovative(Gunduz \& Ozcan, 2017). Thus, using learning platform like Edmodo is worth trying, not only to make the language learning more interesting but also as an effort to integrate some values such as collaboration, innovation and communication into language learning.

Regarding to the background, two research questions were formulated in this study. Both are what are students' perceptions toward the implementation of Edmodo? And What classroom activities can be done in Edmodo? To answer the two questions, this study was supported with some theoretical language framework such as technological enhanced language learning, online learning, and ESP (English for Specific Purposes). The novelty of this study lies in using Edmondo in ELT classes and it is focused on students' perception and learning activities during implementing Edmundo in terms of the ESP setting.

\section{Technology Enhanced Language Learning}

The appearance of industrial revolution 4.0 (IR 4.0) is marked by the innovation and advance of technology in all parts of people's life. It changes how people live, interact, work and learn. It impacts in all parts of people's life including education. The milennial generation -known as Gen Z- who are now becoming students in schools has ability in using the product of technology which later change their attitude toward learning. In reference to this phenomenon, teaching and learning have to change to cope with the need of Gen $\mathrm{Z}$. (Shahroom \& Hussin, 2018) stated that teaching and learning will experience changing in the ways it's delivered or done. In line with this, the content of the teaching, roles of lecturers and students have changed. The logic of education systems should be reversed so that it is the system that conforms to the learner rather than the learner to the system. The point of the changing may deal with personalisation as well as the integration of technology into learning. 
A common understanding of technology refers to computer equipment, software and other electronic devices that make human's life easier (Spector, 2014). While Isman (2012) in (Ahmadi, 2018) defines technology as the practical use of knowledge particularly in a specific area and is a way of doing a task especially using technical processes, methods, or knowledge. It is added that technology use does not only cover machines and intruments. It is related to humans, machines and environment. In line with this, technology integration can simply mean the use of technology in the classroom. However, technology integration is not only about using the equipment in teaching-learning. It deals more with efforts to establish innovative and creative best practices as they progress in gaining access to new and developing digital technologies (ISTE, 2008; Woolfe, 2010) and implement it in education (Spector, 2014).

Smith and Barber (2007) in (Jati, 2017) state that the development of technology had given teachers option to incorporate it into teaching and learning. They added that such technology could empower and improve the teaching. This statement supports the use of technology in the field of teaching and learning, as technology can enrich the experience provided by technology to students. The tools produced by technology provide learners to involve in a more meaningful learning especially in language learning.

Many researches have already discussed on how to create environment for language learning. The environment should be able to encourage learners to experience the language use in a meaningful context. In this case, technology has an important role. Jati (2014 in (Floris, 2014) gave an example of using CSM (Cartoon Story Maker) in a language classroom. CSM enables learners to 2D screen based cartoon series. Learners can practice make dialogue through this tool. Learners can create dialogue using text as well as their own voice to practice fluency and pronunciation. They can also use their own picture to act out the situation and voice or text which match the situation. Teachers can also take part by providing script or situation so learners can create the conversation. It can be said the the integration of technology is possible and enrich the language learning process. Learning involved in the activity and they may not realize that those are assignment. On the other hand, it resembles to the daily converse that they possible participate.

In addition to providing meaningful context to learn and practice, technology also provides abundant of learning resources, especially for language learning. Learners may select applications as well as web site to support their learning (Haerazi et al., 2020). For example, podcasts have been popular to be used to learn listening skills, while website such as CNN, www.breakingnewsenglish.com and many other websites cater learners needs in term of preparing materials for reading and listening skills.

The use of video or films can also support the language learning. Those two can be integrated in learning creatively as it is interesting for the content of visual and audio it has. Both films and video can help learn speaking and listening skills. (Chen, 2018) implemented the making of video as a project in a speaking class. This study was conducted in an EFL course called Freshmen English in a Taiwan university. Students were asked to create a video project to practice speaking skills as well as build their empathy. The result of this study showed that students were able to improve their speaking skill by creating a video project. In addition, students also learn to express their empathy through the video they watched. The video project also equipped students with other skills such as teamworking, active listening skill, and video production skills which also cover mastering how to use technology tools.

As it has been discussed, technology and technology integration in language learning has enrinched and empowered the learning process. Moreover, it equips the learning with meaningful context which is similar to the real world situation. Then, the integration of technology in language learning must become concerns of every teacher and school to make language learning more up to date and relevant to the todays world situation. 


\section{Online learning}

The term online learning, e-learning, web-based learning, distributed learning and learning with ICT are commonly used to refer to e-learning. It is simply defined as learning which occur through the electronic tool as well as internet. The point is a process of learning which is assisted, empowerd and enriched by the internet. Dabbagh and Bannan-Ritland in (Prawiradilaga, 2012) defined online learning as an open and distributed learning environment that uses pedagogical approache, enabled by internet and web-based technologies, to facilitate learning and knowledge building through meaningful action and interaction.

The definition points to some keywords such as pedagogical approache, internet and web based technologies as well as meaningful action and interaction. Then, it can be illustrated that online learning in a process of teaching and learning that occur with the medium of internet technology and contain meaningful activities which involve learners and teachers.

U.S Departement of Education (2010) in (Gilbert, 2015) defined online learning as learning that takes place partially of entirely over the internet. This type of learning can be categorized into three main groups, namely; fully web based, blended or hybrid format, and traditional courses using web based supplements. Fully web based courses are conducted entirely on the Internet with no face to face interaction, all aspects of the course being conducted in an online learning environment. Hybrid courses consist of both web based and classroom sessions, with a varying degree of time allotted to the online and in class sessions, depending upon the nature of the class and discretion of the instructor. The last programming format uses online technology as a medium for presenting supplemental material for traditional classroom study

Another definition of online learning was explained by (Bartley \& Golek, 2004; Evans \& Haase, 2001) in (Nguyen, 2017) as a form of distance learning or distance education, which has long been a part of the American education system, and it has become the largest sector of distance learning in recent years. It is said to be the part of distance learning, since the support of online learning was common in the implementation of distance learning. Tools like computer, internet, learning platform and other tools based on technology are usually used with the term.

Dabbagh and Bannan-Ritland describes three main components in online learning in the following figure.

Pedagogical model/construct

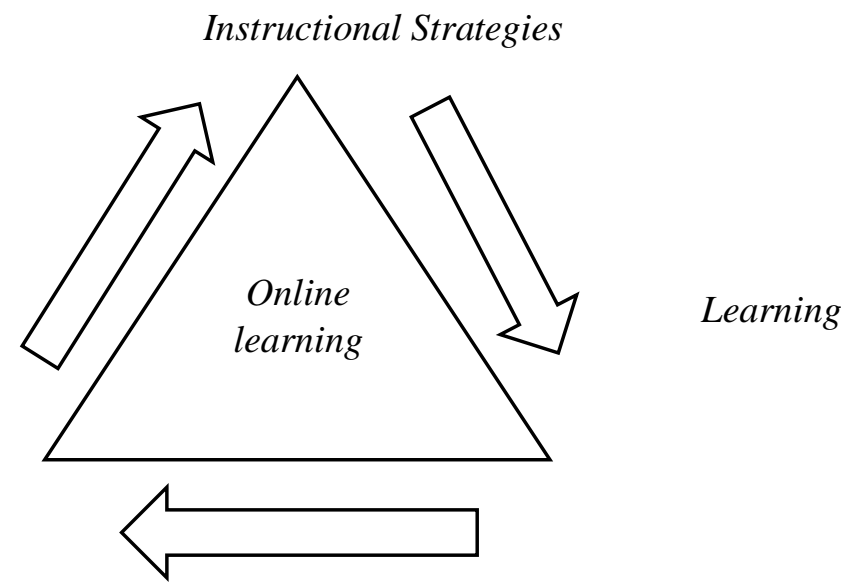

Figure 1. Three Main Components of Online Learning (Dabbagh and Bannan-Ritland 2005 in (Prawiradilaga, 2012)

Figure 1 shows that the three main components of online learning are pedagogical model/construct, instructional strategies and learning technologies. These three components must involve in online learning, so learning activities can be said as supported by online. Pedagogical content is significant since it is the primary sign that the activities occured are 
related to learning. While instructional strategies are the strategies of how learning is delivered. For example it uses problem-based, project-based or task-based learning. The technologies are the tools used to support the teaching learning activities. Some examples can be in the form of learning platform.

\section{English for Specific Purposes \\ Previous Studies: Edmodo in EFL}

Some studies regarding the use of Edmodo have been conducted, and those studies reported positive results. (Al-Kathiri, 2015) investigated the use of Edmodo in Saudi Female secondary school. The research was focused on students perceptions, challenges and attitudes in reference with the use of Edmodo. The study that used experimental method stated that students had positive perceptions and that Edmodo was potential to be integrated in the EFL class since it generated positive attitude for students. In terms of learning English, students stated that Edmodo is helpful in acquiring new English vocabulary, sharing their writing with teachers and peers, enjoying reading experiences and developing listening skill. It can be concluded that Edmodo is possible to provide an environment in which communication skills especially in English can be practiced through the use of its features.

Edmodo is also used to teach writing argumentative essay in a higher education institution. The research conducted by (Miftah, 2018) discussed this. The research was done using classroom action research (CAR) to 15 students joined in a course called Argumentative Writing. The result showed that students' ability to produce argumentative essay increased after Edmodo was implemented. There were some steps applied in using Edmodo to teach writing as follows; prepare the teaching materials, introduce Edmodo, guide students to get ready to use Edmodo, give an opportunity to students to get in the Edmodo group, train students to use Edmodo group, group students into small group via Edmodo, give students writing tasks through Edmodo, provide a guideline and tell students to follow the guideline to access their small group, ask students to post their first drafts of an argumentative essay on their small groups, ask students to give feedback on their peers' works, ask students to revise their drafts of the argumentative essay based on the their peers' feedback and teacher, and ask students to post their final products of an argumentative essay on their Edmodo account.

Thus, the research shows us that Edmodo can bridge students' to do collaborative work in the form of small group. In addition, this small group mediated through Edmodo is seen to be effective in providing discussion room and feedback regarding students' writing ability. It means Edmodo is a good place to train students' communication skills as it provides meaningful communication among students, specifically students in the small group.

A study about implementing Edmodo in higher education context was conducted by (Hakim \& Kodriyah, 2016). Edmodo was used to teach three different courses like vocabulary, research method and english grammar. The researchers stated that the use of Edmodo make it easier for the class to create community to practice English. Moreover, discussion between teachers and students can happen anytime even when the class was already finished. Edmodo gives teachers and students opportunity to communicate and strengthen their relationship. Edmodo also encourage students to do collaborative work. Students learn to create assignment using digital content, which develop their skills in using technology.

A study on the use of Edmodo was also conducted by (Serafim \& Meireles, 2019). In their study, Edmodo was used as a tool to implement flipped and expanding classroom. Edmodo was used since it has some features that are believed to be able to support the personalisation required in today's EFL classes. It was stated that Edmodo with its features could accomodate the various needs of students. The features that were being discussed are spotlight in which it can be used with Edpuzzle to learn listening skill. Students can move 
with their pace through Edmodo since the material presented can be repeated many times. In addition, students can work one-on-one both with teacher or with the small groups. Thus, students can be more motivated and comfortable since they can reach the teacher and their groups anytime.

\section{RESEARCH METHOD}

This study was a case study. Case study is said to be the typical research in social science. It might include experiment, action research, survey, naturalistic research, participatory research, historical research etc., and case study research uses multiple methods for data collection and analysis (Cohen, Manion, \& Morrison, 2018). Cresswel (1994 in Cohen et al., 2018) defines the case study as a single instance of a bounded system, for example a child, a clique, a class, a school, a community, others would not hold to such a tight definition. Thus a case study observe phenomenon limited to certain groups. The phenomenon observed can be used to generalize some other groups or units which share the similar phenomenon. In this study, the phenomenon being observed occured in the classroom context. Since it is going to be used to explain certain phenomenon in teaching English for specific purposes (ESP).

This study uses descriptive qualitative methode to explain students' perception as well as the activities applied in GMF classroom and the reasons teacher did the activities. $24 \mathrm{GMF}$ students were the participants of this study. The students were in the second semester of Electronic Avionic (EA) major in Diploma III Electronic Engineering study program. EA class consisted of 22 males and 2 females students. GMF students took English as a subject for just two semesters which was given 4 hours a week.

The instruments used in this study were questionnaire and interview questions. Classroom observation was also done for 10 weeks during the implementation of Edmodo. The observation was recorded using video camera. Before Edmodo was implemented, students and teacher were given tutorials of how to operate Edmodo. After the tutorials were finished, trial session was conducted to check whether teacher and students were already able to use Edmodo. Having passed the trial session, Edmodo was started to be implemented.

\section{RESEARCH FINDINGS AND DISCUSSION}

The following section presents the research findings and discussion. For research findings some tables and screen shots of students' activities in Edmodo will be presented.

\section{Research Findings}

The results of the data analysis will be presented as follows;

\section{Students' Perception towards the use of Edmodo}

Table 1. Students' Perception toward Edmodo

\begin{tabular}{llccccc}
\hline No & \multicolumn{1}{c}{ Statements } & $\begin{array}{c}\text { Completely } \\
\text { disagree } \\
\%\end{array}$ & $\begin{array}{c}\text { Not really } \\
\text { agree } \\
\%\end{array}$ & $\begin{array}{c}\text { Neutral } \\
\%\end{array}$ & $\begin{array}{c}\text { Agree } \\
\%\end{array}$ & $\begin{array}{c}\text { Completely } \\
\text { agree } \\
\%\end{array}$ \\
\hline $1 \quad$ & $\begin{array}{l}\text { Edmodo helps me improve learning } \\
\text { through explanation, quizzes and other } \\
\text { online tasks }\end{array}$ & 0 & 4,2 & 4,2 & 45,8 & 45,8 \\
\hline 2 & $\begin{array}{l}\text { References from internet like video, link, } \\
\text { article and pictures uploaded by lecturer } \\
\text { are useful to understand the subject }\end{array}$ & 0 & 0 & 8,3 & 37,5 & 54,2 \\
\hline 3 & Edmodo is an additional creative & 0 & 0 & 8,3 & 29,2 & 62,5 \\
\hline
\end{tabular}




\begin{tabular}{|c|c|c|c|c|c|c|}
\hline & $\begin{array}{l}\text { teaching methode which can support face } \\
\text { to face interaction in the classroom }\end{array}$ & & & & & \\
\hline 4 & $\begin{array}{l}\text { Comments and feedback from lecturer } \\
\text { and peers have positive impact toward } \\
\text { my English skills }\end{array}$ & 0 & 4,2 & 12,5 & 37,5 & 45,8 \\
\hline 5 & $\begin{array}{l}\text { Edmodo helps me to communicate using } \\
\text { English outside class }\end{array}$ & 0 & 8,3 & 20,8 & 25 & 45,8 \\
\hline 6 & Edmodo makes learning more effective & 0 & 0 & 8,3 & 54,2 & 37,5 \\
\hline 7 & $\begin{array}{l}\text { Edmodo contributes to development and } \\
\text { academic achievement }\end{array}$ & 0 & 0 & 3 & 37 & 60 \\
\hline
\end{tabular}

From the table it can be seen that most students have positive perceptions toward the use of Edmodo. 45,8\% students think Edmodo helps them improve learning the explanation, quizzes and online tasks. They also have positive opinion regarding the availability of references provided through Edmodo. It can be seen through 54,2 \% students who selected 5 for this point. $62,5 \%$ students completely agree that Edmodo is a creative teaching methode and support face-to-face interaction. In addition, students feel that Edmodo make their learning more effective. It is also supported from the interview result, which said that using Edmodo make it possible to access information presented by the teacher anytime. Moreover, most materials are available in the form of text, pictures, power point presentation and video which accomodate students with various learning style. In question 7, 60\% students completely agree that Edmodo contributes to their development and academic achievement. This positive perception may be caused by the compatibility of this learning platform with students who are mostly milenials generation.

\section{Advantages of Edmodo}

The following table presents the advantages of Edmodo. Numbers presented are in percentage.

Table 2.The Advantages of Edmodo

\begin{tabular}{|c|c|c|c|c|c|c|}
\hline No & Statements & 1 & 2 & 3 & 4 & 5 \\
\hline 1 & $\begin{array}{l}\text { Edmodo helps me to interact with peers } \\
\text { and lecturer about the subject being taught } \\
\text { via online }\end{array}$ & 0 & 0 & 4,2 & 41,7 & 54,2 \\
\hline 2 & $\begin{array}{l}\text { Edmodo is easy to use because I can do } \\
\text { quizzes and tasks online }\end{array}$ & 0 & 0 & 0 & 37,5 & 62,5 \\
\hline 3 & $\begin{array}{l}\text { Edmodo helps me access more references } \\
\text { which is available online as well as } \\
\text { material uploaded by lecturer }\end{array}$ & 0 & 0 & 0 & 58,3 & 41,7 \\
\hline 4 & $\begin{array}{l}\text { Online activities and discussion motivate } \\
\text { me to study the subject being presented }\end{array}$ & 0 & 0 & 16,7 & 45,8 & 37,5 \\
\hline 5 & $\begin{array}{l}\text { Edmodo can save time and money } \\
\text { especially to get information and } \\
\text { interaction with peers and lecturer }\end{array}$ & 0 & 0 & 4,2 & 54,2 & 41,7 \\
\hline
\end{tabular}

The point of advantages of Edmodo shows positive result which can be seen from the statement and percentage in the table. 54,2\% students completely agree that Edmodo helps them interact with peers and lecturer about subject being taught. Additionally, 62,5\% students also completely agree that Edmodo is easy to use for quizzes and online tasks. It can be seen from the table that $0 \%$ students disagree for this point and only $37,5 \%$ agree. In point 3 , $58,3 \%$ students agree that Edmodo helps them access online references and materials uploaded by lecturers. Online references are abundant and various, thus students can get wider range of knowledge and information. They can also learn to recognize reliable sources from unreliable ones. For point 4, 45,8\% students agree that online activities and discussion 
motivate them to study the subject being presented. Possibly because the activities and discussion are enriched by different forms of resources. Finally in point 5, 54,2\% students agree that Edmodo can save time and money to get information and involve in interaction with peers and lecturer. It can be concluded that students think Edmodo has many advantages for their learning.

\section{Students' Perception toward Disadvantages of Edmodo}

The following table presents the disadvantages of Edmodo;

Table 3. Disadvantages of Edmodo

\begin{tabular}{llccccc}
\hline No & \multicolumn{1}{c}{ Statements } & 1 & 2 & 3 & 4 & 5 \\
\hline 1 & $\begin{array}{l}\text { Online activities such as tasks, quizzes } \\
\text { and discussion waste my time }\end{array}$ & 17,4 & 26,1 & 30,4 & 8,7 & 17,4 \\
\hline 2 & $\begin{array}{l}\text { Students who dont have internet access } \\
\text { can be left behind }\end{array}$ & 20,8 & 20,8 & 20,8 & 20,8 & 16,7 \\
\hline 3 & $\begin{array}{l}\text { Students have to spend a lot of money for } \\
\text { Edmodo }\end{array}$ & 29,2 & 37,5 & 12,5 & 4,2 & 16,7 \\
\hline 4 & $\begin{array}{l}\text { The use of Edmodo is difficult because } \\
\text { many features are difficult to learn }\end{array}$ & 54,2 & 41,7 & 4,2 & 0 & 0 \\
\hline
\end{tabular}

For point 1 , students who select neutral is $30,4 \%$. This is quite surprising. The interview result shows that this opinion is triggered by slow internet connection as well as slow response of the application. This draw back can be taken as advice for the application to improve. Point no 2 shows interesting result, in which for point completely disagree, disagree, neutral and agree the number of percentage is $20,8 \%$. This perhaps is the sign of doubt since internet has become very important for students nowaday. The result of interview said that students mostly rely on internet for doing assignment, searching for references and exploring deeper information about the subject being learned. Point 3 presents that 29,2\% students completely disagree and $37,5 \%$ disagree that students have to spend a lot of money for Edmodo. It means this disadvantages are not serious problem for students. It is possible caused by GMF students are mostly mid to high class in terms of financial ability. Point no 5 shows that $54,2 \%$ students completely disagree related to the difficulty of Edmodo features. The result of interview said that Edmodo is very similar to facebook. Meanwhile, most students are already familiar with facebook, thus using Edmodo is relatively easy for them.

\section{Classroom Activities using Edmodo}

Some classroom activities are proposed in GMF class. These activities are not only giving quizzes, tasks and sharing materials to substitute lecturer' absence. On the other hand, activities like presenting video about giving useful tips, making story (or status like in facebook) in English, discussion about materials being presented as well as commenting to other groups presentation are given to students. This make the interaction through Edmodo happen and encourage students to use English in a context which is meaningful. As has been known that vocational students learn English primarily for interaction and communication. Therefore, providing environment in which English is used in a real-life-like situation may encourage and improve students' English ability. In the following the screenshot of the activities will be presented; 


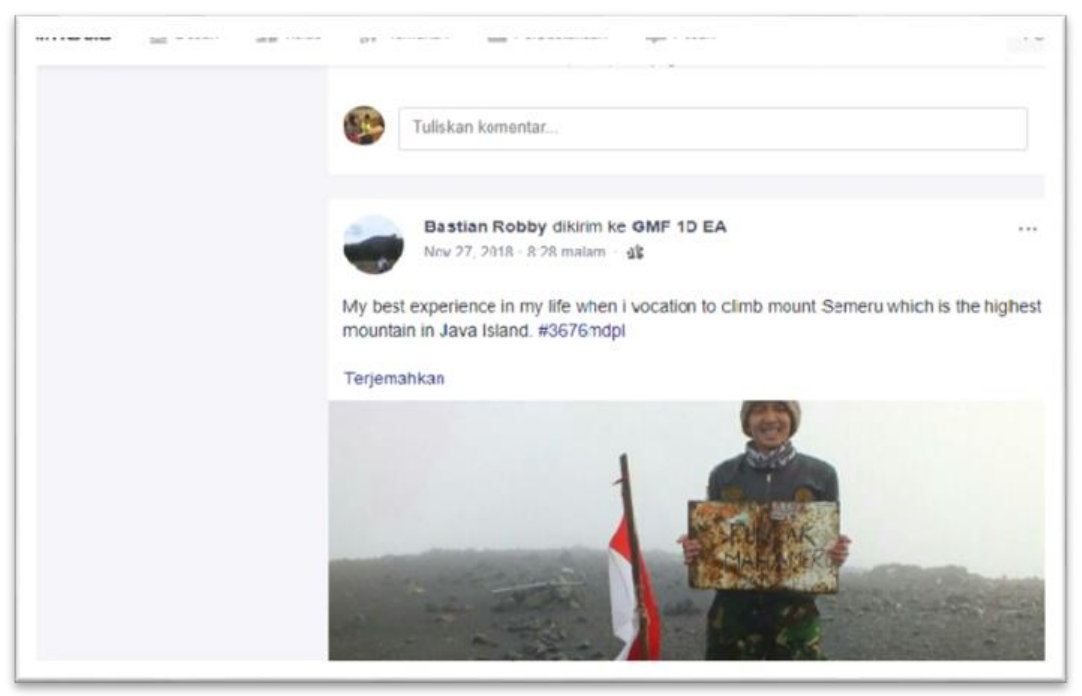

Figure 2. Sharing Story with Simple Sentences

(Source www.edmodo.com GMF 1D EA Class)

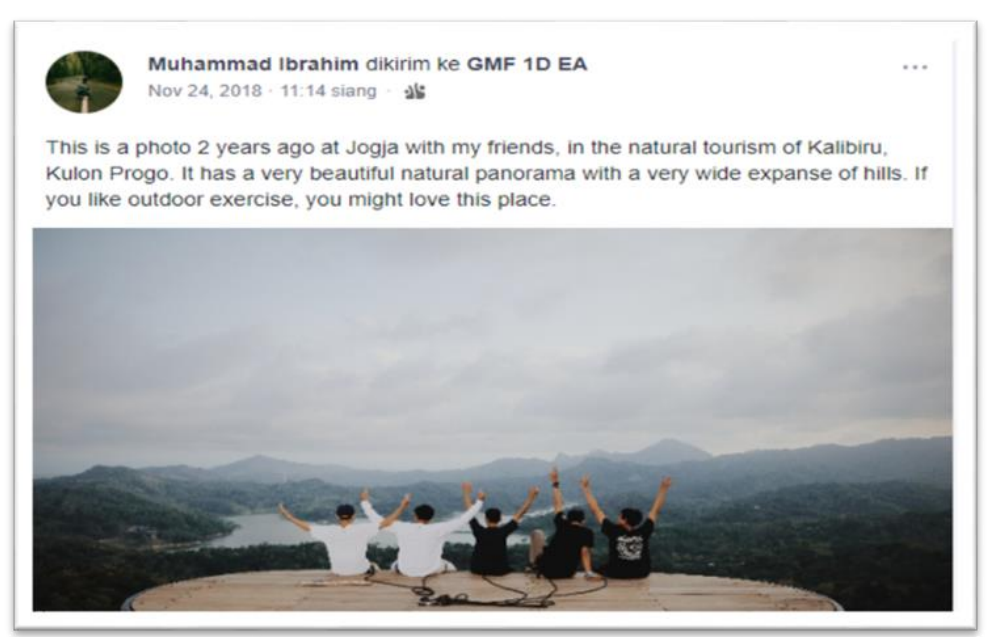

Figure 3. Sharing Story with More Complex Sentences

(Source www.edmodo.com GMF 1D EA Class)

Sharing story such as usually done via facebook is given as one of activities. This is done to train students' ability in composing sentences. One of materials in GMF class is about types of sentences. If students are only asked to make sentences and say it in turn, it seems to be boring. Thus, lecturer ask students to post their story in turn. Peers are obliged to ask questions or comments. This make students more interested in studying the material as well as practicing it. Even though sentences produced still contain mistakes, this activities encourage students to take part both in giving comments and asking questions. The story posted also must meet some criteria like it is about past experience or unforgettable experience, the picture does not contain elements of pornography and sentences must use correct words and tenses. Students are very enthusiastic to join this activity. They try hard to post their best picture to attract their peers to give comments and ask questions.

The following pictures show how students give comments. Even though mistakes are still made, but students do effort to give comments. 


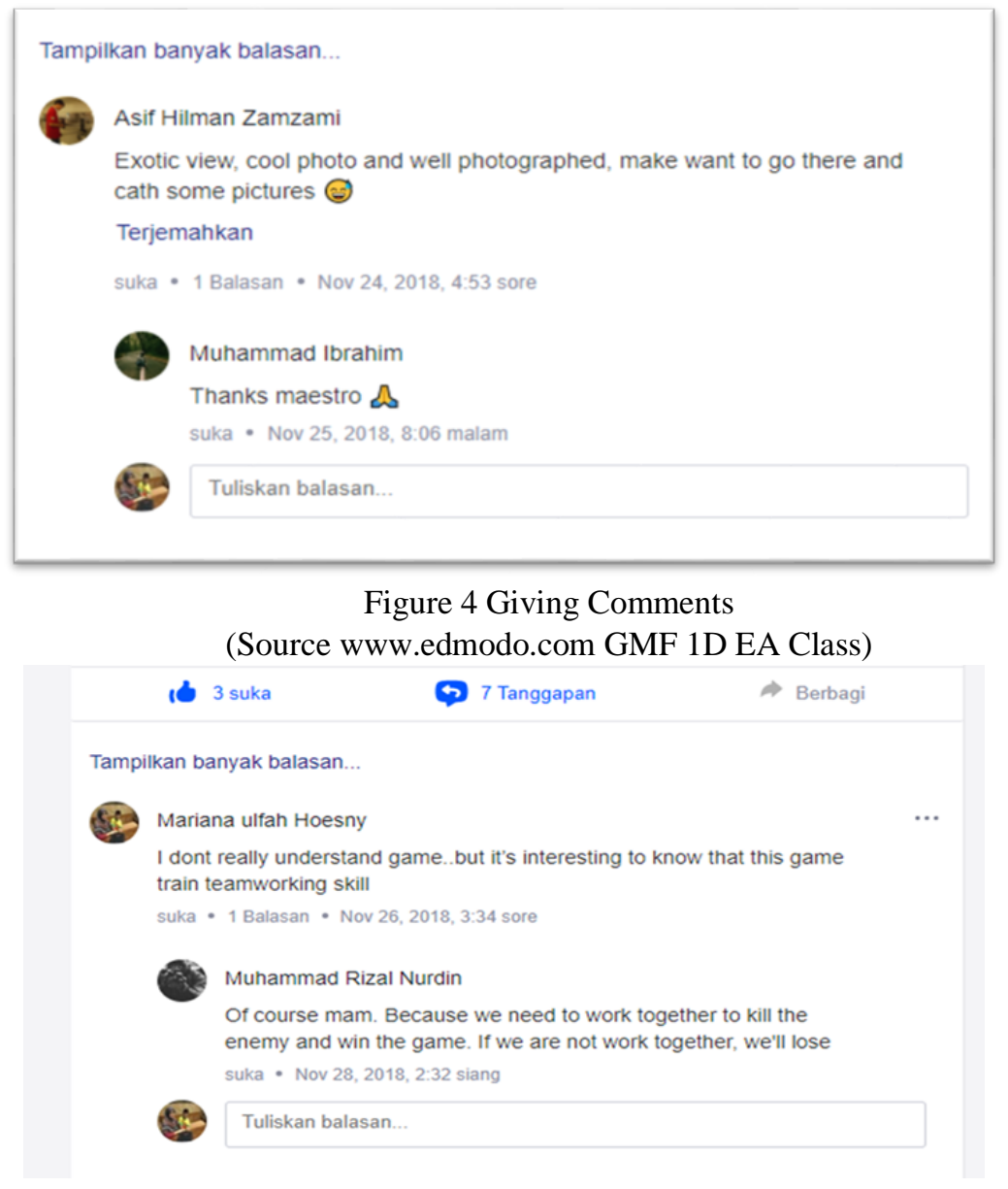

Figure 5 Answering Questions

(Source www.edmodo.com GMF 1D EA Class)

The lecturer also joined to ask questions to students' post. This is done to make students realize that lecturer pay attention to their activities. It can be seen from thee picture that students try to answer the questions.

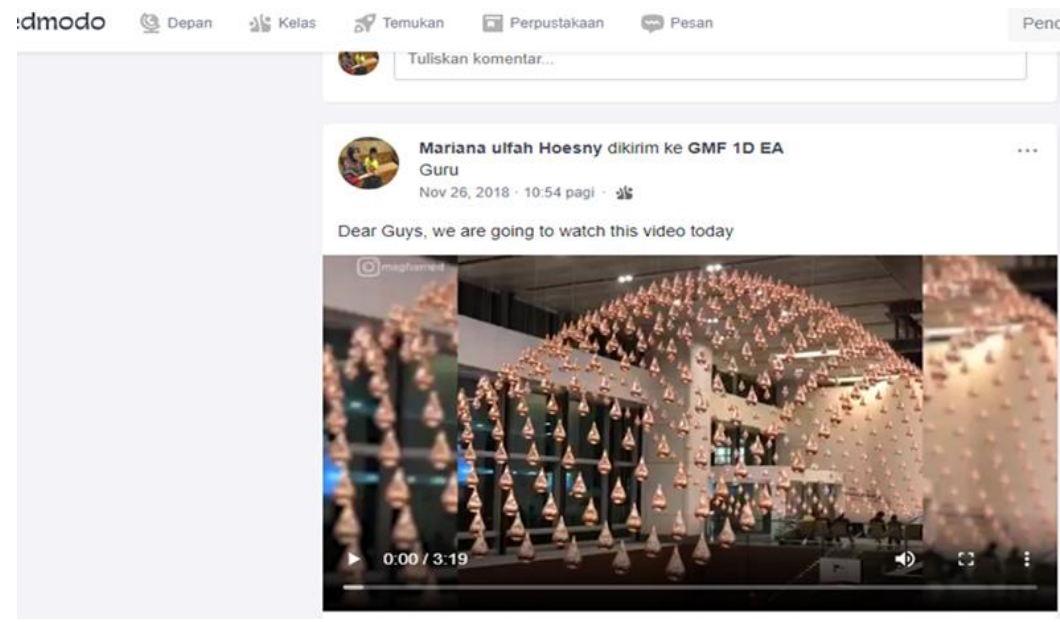

Figure 6. Sharing Video Material (Source www.edmodo.com GMF 1D EA Class) 
Edmodo has a feature in which it provides students' or lecturer's post with attachment. This is found to be helpful. Usually video is played via LCD projector which is available in each class. However, sometimes the LCD does not work or students need more time to understand the video. By sharing video or power point material through Edmodo students can take more time to watch and understand the video. The video can be played many times individually or in a group of students. This can motivate students to have discussion as well.

\section{Discussion}

The result of this study is in line with (Abdulrahman, 2016) that Edmodo has been a supplemental part in traditional classroom. In addition, it resulted in positive response from students since Edmodo has many features that support learning. Edmodo supported shy students to be more participative and confident in the classroom activities since the interaction is mediated by learning platform. The study also added that Edmodo encouraged students to work collaboratively which can help develop students collaborative skill.

The result of questionnaire on students' perception show that students have positive perception toward the use of Edmodo in learning English. This is supported as well by the study of (Kodriyah, 2015) that stated Edmodo was an effective learning tool. It also revealed students' positive response toward the use of Edmodo in the learning activities. The reslut of the study said that Edmodo helped students to understand specific learning course. It is in line with the result of the questionnaire in terms of students' perceptions. Students agree that Edmodo help them improve learning through explanation, online quizzes and tasks. Students also agree that Edmodo is effective and a creative learning tool to support face-to-face interaction. Students think that Edmodo is interesting because it is update and supported by technology. Opinion regarding Edmodo as interesting learning tool could be related to the characteristics of students participated in the class. Students of GMF mostly aged 18-19 years old, in this age they are very familiar with internet and the products of technology. Therefore, the support of Edmodo in the classroom may encourage them to take active part in the learning activities.

Additionally, students believe that comments and feedback from lecturer give positive impact. From the interview held with 10 students, they mostly agree that comments and feedback encourage them to improve and involve in the activities. When lecturer gives comments and feedback students feel that lecturer pays attention, not only making Edmodo as the substitute of lecturer' absence. The encouragement students get from comments and feedback later cause students to improve their academic achievement. Thus, Edmodo can contribute to students' achievement and development.

Regarding with the advantages of Edmodo, a study conducted by Marlina (2013) in (Ramdani, 2014) showed that Edmodo was easy to operate and provided acces to pleasure while learning. It is pleasure since abundant sources can be made available in Edmodo. The sources of learning can be in the form of video, audio, power point and many more. (Chada, 2013) added that Edmodo provided opportunities for learners development. It is in terms of the learning platform enable students to learn a material in advance and review the material after the class is over. While good students can also take benefits from this learning platform since the can study twice more often.

Other advantages of Edmodo it encourages students to be more discipline in doing tasks and train responsibility. This is also found by(Laili \& Nashir, 2018) that Edmodo is good for developing students' discipline. When a task is given via Edmodo, teacher can set the due date so students must submit it on time. Other advantages of Edmodo were proposed by Balasubramanian, Jaykumar, and Fukey (2014) in (Laili \& Nashir, 2018) that Edmodo can be motivating and good media of teaching for it is new innovation and can be implemented in teaching and learning. It is added that Edmodo can motivate students to be autonomous learners. 
The result of those studies are in line with the advantages of Edmodo presented in this study. Moreover, Edmodo is an application that can also be installed in smartphone, students can open it anytime and anywhere. Therefore, interaction happens anytime. Students may ask questions or participate by giving comments and questions to their peers' presentation or task anytime. This is found to be helpful. In addition, Edmodo is easy since many features are available including for giving online quizzes and tasks. Various kinds of quizzes are available in Edmodo and time for submitting the quizzes can also be set. Thus, students learn to be discipline as well. Edmodo provides space for online activities and discussion. Shy students can participate without being afraid to make mistakes. This is very beneficial for those who are still in doubt to give comments and ask question in a face-to-face interaction.

Even though it has been presented that students have positive perception toward Edmodo, some disadvantages of Edmodo are also discussed. The main disadvantages is the availability of internet. Edmodo needs internet connection to be operated which means wifi or data package must be connected. Unfortunately, the wifi is not really good mainly to be accessed by students. While for data package, students must spend more money. In addition, sometimes the application response slowly which make students' questions, comments and involvement in discussion cannot be done fast. This perhaps can be suggestion for Edmodo team for improvement. Other points related to disadvantages of Edmodo are not proved. Such as the difficulties in using Edmodo and much money has to be spent for Edmodo. It means that Edmodo is easy to use, perharps because the features available are similar to facebook which is already popular among students.

Activities that can be done via Edmodo are various. (Chada, 2013) explained that activities of both teachers and students can be seen via Edmodo. Teachers can post tasks and give feedback online. Students also can give comments or question regarding the tasks and feedback through Edmodo. In addition to the study, this study presented some students' activities done through Edmodo, it can be seen from some screen shots presented that students use their English in a real-life-like contexts. Students try to use English as much as they can. Activities such as sharing story, provide students with opportunities to compose sentences. Instead of just saying or writing it, lecturer asks students to make some sentences along with their best pictures and post it so their peers can see and give comments or ask questions. This is surely different with types of tasks students usually do in classroom. This activity seems to be meaningful so students can use various vocabularies to describe their picture. This later can develop their English.

\section{CONCLUSION}

The result of questionnaire and interview shows that Edmodo has many advantages and only a few disadvantages. Students believe that Edmodo is positive tool for learning as they state that it is effective and creative tool to support teaching and face-to-face interaction. It is also positive in term of providing students with many references that are available online and can be in various forms. In terms of advantages, Edmodo is said to be able to help students interact with peers and lecturer. In addition, the features provided are easy to use. It is also added that online discussion and activities motivate them to study the subject being taught. Edmodo is also effective since it saves time and money to get information and take part in classroom interaction anytime and anywhere.

A tool is created by human, Edmodo also has some disadvantages. Main disadvantage is the slow internet connection required to access Edmodo. Furthermore, the application is also slow sometimes which cause materials uploaded both by lecturer and students are not delivered on time. Thus, students' responses are also late. In line with this, students who do not have internet connection or internet package can be left behind. 
In terms of activities done via Edmodo, it can be concluded that students enjoy activities that involve interaction and communication that is similar to real life situation. For example, asking question after video presentation, giving comments and advice are considered interesting. The activities mentioned also give students opportunities to practice their communication skills. However, Edmodo is a tool which needs human to operate. The positive impact of Edmodo towards students' learning depends on lecturer involvement and creativity to make Edmodo a meaningful place to practice and learning English.

\section{REFERENCES}

Abdulrahman, T. (2016). Edmodo as a Supplementary Tool in EFL Classroom: Perception and Reality. In The Bandung International Conference on Language and Education (pp. 39-50). Bandung. Retrieved from https://www.academia.edu/35083705/Edmodo_as_a_Supplementary_Tool_in_EFL_Clas sroom_Perception_and_Reality

Ahmadi, M. R. (2018). The Use of Technology in English Language Learning: A Literature Review. International Journal of Research in English Education (IJREE), 3(2), 115125.

Al-Kathiri, F. (2015). Beyond the Classroom Walls: Edmodo in Saudi Secondary School EFL Instruction, Attitudes and Challenges. English Language Teaching, 8(1), 167-180. https://doi.org/10.5539/elt.v8n1p189

Chada, K. (2013). How Edmodo and Google Docs Can Change Traditional Classroom. In The European Conference on Language Teaching.

Chen, C. W.-Y. (2018). Developing EFL students' digital empathy through video production. System, 77, 50-57. https://doi.org/10.1016/j.system.2018.01.006

Cohen, L., Manion, L., \& Morrison, K. (2018). Research Methods in Education (8th editio). Oxon: Routhledge.

Floris, F. D. (2014). Using Information and Communication Technology (ICT) To Enhance Language Teaching \& Learning: an Interview With Dr. a. Gumawang Jati. TEFLIN Journal, 25(2), 139-146. https://doi.org/10.15639/teflinjournal.v25i2/139-164

Gilbert, B. (2015). Online learning revealing the benefits and challenges. Education Masters, 1-34. Retrieved from http://fisherpub.sjfc.edu/education_ETD_masters

Gunduz, N., \& Ozcan, D. (2017). Implementation of the Moodle System Into EFL Classes Implementación del sistema Moodle en las clases de inglés como lengua extranjera, 19, 51-64. https://doi.org/10.15446/profile.v19n_sup1.68571

Haerazi, H., Utama, I., \& Hidayatullah, H. (2020). Mobile Applications to Improve English Writing Skills Viewed from Critical Thinking Ability for Pre-Service Teachers. International Journal of Interactive Mobile Technologies (IJIM), 14(07), pp. 58-72. DOI: http://dx.doi.org/10.3991/ijim.v14i07.11900

Hakim, A. R., \& Kodriyah, L. (2016). Edmodo: an Effective Solution To Blended Learning for Efl Learners. Proceedings of the 1st National Conference on English Language Teaching (NACELT), (November 2015), 23-32.

Inayati, A. M. et. a. (2019). Edmodo in English Language Learning: A Review of Recent Studies. Jurnal Ilmiah Kependidikan, 12(2), 111-122.

Jati, G. (2017). Perspective on Ict in Teaching and Learning Listening \& Speaking in the 21 St Century: Beyond Classroom. Journal of Teaching and Learning English in Multicultural Contexts, 1(1), 16-29. Retrieved from http://jurnal.unsil.ac.id/index.php/tlemc/article/download/395/309

Kodriyah, L. (2015). Students' Perceptions toward the Use of Edmodo as an Effective Tool for Learning English. 
Laili, R. N., \& Nashir, M. (2018). The Effect of Blended Learning by Using Edmodo in Teaching English for Nursing Students. Indonesian Journal of Curriculum and Educational Technology Studies, 6(2), 71-76. https://doi.org/10.15294/ijcets.v6i2.26509

Miftah, M. Z. (2018). Utilization of Edmodo as an Online Tool in EFL Writing Class to Increase Students' Writing Ability. Register Journal, 11(1), 37. https://doi.org/10.18326/rgt.v11i1.37-58

Nguyen, T. T. (2017). Developing Important Life Skills through Project-Based Learning : A Case Study. The Normal Lights, 11(2), 109-142. Retrieved from https://pdfs.semanticscholar.org/d85d/6dbedf4ebf63c425fca4c929441857409b9b.pdf

Okumura, S., \& Bronson, M. (2016). The Use of Edmodo to Enhance Second Language Learning among Japanese and American College Students. International Research Conference on Japanese Language Education, (September), 0-3.

Prawiradilaga, D. S. (2012). Wawasan Teknologi Pendidikan (1st ed.). Jakarta: Kencana Prenada Media Grup.

Ramdani, J. (2014). Optimizing the use of edmodo in grammar class. In Siliwangi International English Conference.

Serafim, V. F., \& Meireles, A. R. (2019). Affordances of Edmodo for the Flipping and Expansion of the L2 Classroom. BELT - Brazilian English Language Teaching Journal, 9(2), 293. https://doi.org/10.15448/2178-3640.2018.2.31963

Shahroom, A. A., \& Hussin, N. (2018). Industrial Revolution 4.0 and Education. International Journal of Academic Research in Business and Social Sciences, 8(9), 314319. https://doi.org/10.6007/ijarbss/v8-i9/4593

Smaldino, S. E. et. al. (2015). Instructional Technology and Media for Learning (11th Editi). Boston: Pearson Education.

Spector, J. M. et. a. (2014). Handbook of Research on Educational Communications and Technology: Fourth Edition. Handbook of Research on Educational Communications and Technology: Fourth Edition. https://doi.org/10.1007/978-1-4614-3185-5 